\title{
Albuterol Sulfate
}

National Cancer Institute

\section{Source}

National Cancer Institute. Albuterol Sulfate. NCI Thesaurus. Code C47957.

The sulfate salt of the short-acting sympathomimetic agent albuterol, a 1:1 racemic mixture of (R)-albuterol and (S)-albuterol with bronchodilator activity. Albuterol stimulates beta2-adrenergic receptors in the lungs, thereby activating the enzyme adenylate cyclase that catalyzes the conversion of ATP to cyclic-3',5'-adenosine monophosphate (cAMP). Increased cAMP concentrations relax bronchial smooth muscle, relieve bronchospasms, and reduce inflammatory cell mediator release, especially from mast cells. To a lesser extent albuterol stimulates beta1-adrenergic receptors, thereby increasing the force and rate of myocardial contraction. 